\title{
Notes on Russian terms, images and abbreviations
}

\section{Russian terms and images}

I have retained Russian names in their transliterated forms (Gor'kii as opposed to Gorky) throughout the manuscript. I have also incorporated as many English translations of the referenced texts as I was able to locate. It is my hope that interested individuals who are unable to read in Russian may still engage this study and the primary texts in translation. For the most part, I have relied on the translated texts in quotes, unless there were clear inaccuracies. All other translations from Russian are my own. Both the Hoover Institute Archive and the United State Literary Museum of I.S. Turgenev were very generous in providing copies of rare photographs of Leonid Andreev for publication in this book.

\section{Abbreviations}

IRLI Institute of Russian Literature, Pushkin House, St Petersburg

LRA Leeds Russian Archive, Leeds University, UK

OGLMT United State Literary Museum of I.S. Turgenev, Orel

RGALI Russian State Archive of Literature and Art, Moscow 
Frederick H. White - 9781526102119 Downloaded from manchesterhive.com at $04 / 26 / 2023$ 02:46:07PM 